\title{
LAYANAN BIMBINGAN KELOMPOK BIDANG KARIR BAGI ANAK BERKEBUTUHAN KHUSUS (TUNAGRAHITA RINGAN) DI SLB NEGERI KANDANGAN
}

\author{
Taufik Akhyar \\ SLB Negeri Kandangan
}

\begin{abstract}
ABSTRAK
Penelitian ini dilatar belakangi oleh pemahaman anak tunagrahita mengenai karir masih rendah, serta mengacu pada tugas perkembangan dan klasifikasi anak tunagrahita ringan yang memiliki keterbatasan inteligensi dan ketidakcakapan dalam komunikasi sosial namun, dengan bimbingan dan didikan yang baik akan dapat memperoleh penghasilan untuk dirinya sendiri. Tujuan dalam penelitian ini adalah untuk mengetahui perencanaan, pelaksanaan, dan evaluasi layanan bimbingan kelompok bidang karir bagi ABK (tunagrahita ringan). Penelitian ini adalah penelitian deskriptif dengan pendekatan kualitatif. Adapun sumber data dalam penelitian ini terdiri dari 1 guru bimbingan dan konseling dan 2 ABK (tunagrahita ringan) sebagai sumber data primer. Teknik pengumpulan data pada penelitian ini menggunakan teknik wawancara, observasi sebagai studi pendahuluan dan dokumentasi. Teknik analisis data pada penelitian ini yaitu pengumpulan data, reduksi data, penyajian data dan penarikan kesimpulan. Penelitian ini menggunakan triangulasi sumber untuk menguji keabsahan data. Hasil penelitian ini menunjukkan bahwa pada tahap perencanaan layanan telah disesuaikan dengan kebutuhan peserta didik melalui proses identifikasi dan analisis kebutuhan peserta didik. Pelaksananan layanan bimbingan kelompok bidang karir bagi ABK (tunagrahita ringan) menggunakan metode respisitory, tanya jawab, dan bermain dalam pelaksanaannya dimodifikasi atau disesuikan dengan kemampuan peserta didik yang berupa alokasi waktu, tujuan, materi, metode, media dan kegiatan layanan. Evaluasi yang dilakukan berupa evaluasi proses dan evaluasi hasil yang dilakukan dalam pelaksanaan kegiatan layanan bimbingan kelompok untuk melihat tingkat keberhasilan layanan yang diberikan, dan hasil yang diperoleh menunjukan bahwa layanan bimbingan kelompok bidang karir memiliki pengaruh terhadap pengetahuan peserta didik (progresif). Adapun kesimpulan dari penelitian ini, pelaksanaan layanan bimbingan kelompok bidang karir bagi ABK (tunagrahita ringan) telah terlaksana dengan optimal. Diharapkan guru bimbingan dan konseling agar lebih bersemangat dalam melakukan inovasi pada pelaksanaan layanan bimbingan kelompok bagi peserta didik berkebutuhan khusus dalam mencapai tugas perkembangannya.
\end{abstract}

Kata Kunci: bimbingan kelompok, karir, tunagrahita

\section{PENDAHULUAN}

Peserta didik berkebutuhan khusus atau yang dikenal sebagai anak berkebutuhan khusus (ABK) merupakan anak yang memerlukan pelayanan spesifik dalam pendidikan berbeda dengan anak pada umumnya. Anak berkebutuhan khusus (ABK) mengalami hambatan dalam belajar dan perkembangan (Dadang Garnida,
2015:1). Salah satu persoalan yang dihadapi anak berkebutuhan khusus (ABK) adalah bagaimana setelah mereka menyelesaikan pendidikan di sekolah. Apakah mereka dapat bersaing dan dapat memilih karir yang layak di dunia yang memandang anak berkebutuhan khusus sebagai sebuah kelainan, keterbelakangan dan bentuk diskriminasi lainnya, sampai saat ini hanya 
Jurnal Inovasi BK, Volume 2, Nomor 1 Juni 2020 sedikit anak berkebutuhan khusus yang dapat kesempatan bersaing memiilih karir yang layak (Mirnawati, 2017:1).

Peserta didik di SMPLB mempunyai tugas perkembangan yang harus dicapai tertera pada Panduan Operasional Penyelenggaraan Bimbingan dan Konseling Sekolah Menengah Pertama (SMP) Kemendikbud Direktorat Jendral Guru dan Tenaga Kerja Kependidikan (2016: 12) terdapat sepuluh tugas perkembangan, salah satunya adalah tugas perkembangan mengenal kemampuan, bakat, minat, serta arah kecendrungan karier dan apresiasi seni.

Bimbingan di sekolah diberikan oleh guru BK kepada peserta didik, proses pemberian bimbingan dapat dilakukan dengan situasi kelompok. Bimbingan kelompok merupakan bantuan terhadap siswa yang dilaksanakan dalam situasi kelompok, bimbingan kelompok dapat berupa penyampaian informasi maupun aktivitas kelompok dengan membahas masalah-masalah pendidikan, pekerjaan, sosial (Juantika Nurihsan, 2014: 23).

Hambatan bagi ABK tentu tidak hanya ditemui ketika dijenjang SMP namun, dikehidupan selanjutnya seperti, menentukan pendidikan lanjutan dan ketika menempatkan diri ditengah masyarakat untuk bekerja. Serlia (2018). Persoalan pendidikan yang dihadapi ABK adalah upaya yang perlu dilakukan dalam menjamin pendidikan lanjutan. Melihat kenyataan bahwa hingga saat ini tidak banyak ditemui ABK yang memperoleh kesempatan bersaing dan memilih karir yang layak. Mengingat kompleksnya hambatan yang dihadapi. Oleh karena itu, bimbingan bidang karir sangat diperlukan bagi ABK.

Penelitian ini difokuskan kepada ABK tunagrahita, melihat kondisi dilapangan bahwa ABK tunagrahita di SLB Negeri Kandangan lemah secara akademik jadi perlu pembekalan life skills dan hasil need assesmen (AKPD) menunjukkan presentase yang cukup tinggi pemilih dalam mengisi pernyataan yang sesuai pada instrument akpd pada bidang karir atau dapat disimpulkan bahwa pemahaman abk tunagrahita ringan pada bidang karir masih rendah, peneliti tertarik untuk mengetahui bagaimana menangani ABK berada di sekolah khusus (SLB) dan mempersiapkan ABK tunagrahita untuk terjun dimasyarakat, memiliki kesempatan yang sama dengan anak pada umumnya untuk memilih karir dengan keterbatasan intelektual yang dimilikinya.

Berdasarkan hasil wawancara studi pendahuluan kepada guru pembimbing khusus (GPK) mengenai ABK tunagrahita informasi yang diperoleh adalah bahwa, ABK tunagrahita diberikan pembelajaran keterampilan untuk membuat telur asin yang dilakukan setiap satu kali dalam satu semester dalam kegiatan pembelajaran life skilss, kemudian pada saat event (ulang tahun sekolah, hari kartini, bulan bahasa) peserta didik tunagrahita diajarkan untuk berwirausaha dengan berjualan, dan kegiatan yang lebih rutin dilaksanakan adalah bina diri pada pembelajaran ini anak tunagrahita diajarkan untuk mencuci piring.

Peserta didik tunagrahita adalah anak yang kecerdasannya dibawah rata-rata dan ditandai oleh keterbatasan inteligensi dan ketidakcakapan dalam komunikasi sosial. Anak tunagrahita dalam Skala Binet dan Skala Weschler dikelompokkan menjadi, tunagrahita ringan adalah anak tunagrahita yang dengan bimbingan dan didikan yang baik akan dapat memperoleh penghasilan untuk dirinya sendiri, anak tunagrahita sedang merupakan anak yang membutuhkan pengawasan yang terusmenerus agar mampu mengerjakan suatu hal yang sering dilakukan, anak tunagrahita berat merupakan anak yang memerlukan bantuan secara total dan memerlukan perlindungan bahaya sepanjang hidupnya (Jati Rinakri, 2018: 101). Dengan demikian anak tunagrahita khususnya kategori ringan masih dapat diberikan bimbingan dan 
didikan pada bidang akademis dan karir di sekolah.

\section{METODE}

Jenis penelitian yang digunakan dalam penelitian ini adalah jenis penelitian deskriptif dengan pendekatan kualitatif yang bertujuan untuk mengumpulkan informasi secara aktual dan terperinci, mengidentifikasikan masalah, membuat perbandingan atau evaluasi, dan mengetahui bagaimana pelaksanaan layanan bimbingan kelompok bidang karir bagi Anak Berkebutuhan Khusus (tunagrahita ringan) di SLB Negeri Kandangan.

Waktu pelaksanaan penelitian yaitu terhitung sejak bulan September di tahun ajaran 2019/2020. Adapun tempat penelitian ini dilaksanakan di SLB Negeri Kandangan yang terletak di Jl. Singakarsa, RT. 05/LK III, Kandangan, Hulu Sungai Selatan, Kalimantan Selatan.

Teknik pengumpulan data pokok menggunakan teknik interview, sedangkan untuk teknik pengumpulan data kelengkapannya dilakukan teknik wawancara, observasi, catatan lapangan dan dokumentasi yang dilakukan di SLB Negeri Kandangan.

\section{HASIL DAN PEMBAHASAN}

Setelah penulis melakukan penelitian yakni melalui wawancara, observasi, dan dokumentasi maka penulis dapat menghasilkan temuan penelitian. Penulis mendapat data yang relavan dan data tersebut diproses dan dikembangkan untuk menjawab rumusan masalah dalam penelitian ini. Khusus untuk menganalisis data berdasarkan hasil wawancara penulis melakukan analisis data dengan tahapan sebagai berikut: pengumpulan data, reduksi data (penyederhanaan data), display data (penyajian data) dan kesimpulan (verifikasi). Adapun data yang disajikan dalam penelitian ini adalah data mengenai pelaksanaan layanan bimbingan kelompok bidang karir bagi ABK (tunagrahita ringan) di SLB Negeri Kandangan.

Berdasarkan hasil wawancara dengan guru BK bahwa untuk mengidentifikasi kebutuhan peserta didik berkebutuhan khusus selain, mengacu pada tugas perkembangan peserta didik yaitu, berdasarkan hasil rekomendasi dari psikolog mengenai kemampuan peserta didik berkebutuhan khusus, melalui pengamatan (observasi), dan hasil need assessment menggunakan instrument AKPD (angket kebutuhan peserta didik) yang menunjukkan bahwa pemahaman ABK (tunagrahita ringan) mengenai karir cukup rendah sehingga, peserta didik berkebutuhan khusus (tunagrahita ringan) memerlukan informasi mengenai karir atau layanan dalam bidang karir.

Berdasarkan hasil need assessment (analisis kebutuhan siswa) yang menunjukkan bahwa pemahaman ABK (tunagrahita ringan) mengenai karir cukup rendah sehingga, perlu diberikan informasi mengenai karir, guru BK membuat perencanaan kegiatan layanan yang membahas tentang karir dengan frame bimbingan kelompok atau layanan bimbingan kelompok bidang karir.

Berdasarkan hasil evaluasi dikaji dan dianalisis kemudian, dilakukan tindak lanjut. Misalnya, hasil evaluasi peserta didik dalam pelaksanaan layanan bimbingan kelompok menunjukkan bahwa beberapa peserta didik masih belum paham maka, dilakukan remedial didalam layanan bimbingan kelompok sampai peserta didik mengerti. Apabila ada kekurangan maka, diperbaiki termasuk program yang kurang tepat akan diperbaiki. Jika dirasa cukup maka diberikan pendampingan.

Berdasarkan hasil evaluasi dikaji dan dianalisis kemudian, dilakukan tindak lanjut. Misalnya, hasil evaluasi peserta didik dalam pelaksanaan layanan bimbingan kelompok menunjukkan bahwa beberapa peserta didik masih belum paham maka, 
Jurnal Inovasi BK, Volume 2, Nomor 1 Juni 2020

dilakukan remedial didalam layanan bimbingan kelompok sampai peserta didik mengerti. Apabila ada kekurangan maka, diperbaiki termasuk program yang kurang tepat akan diperbaiki. Jika dirasa cukup maka diberikan pendampingan. Bentuk tindak lanjut dalam pelaksaan bimbingan kelompok bidang karir bagi ABK (tunagrahita ringan) adalah dengan menyediakan wadah dan pengajaran bagi ABK untuk melakukan kegiatan menari dan bermain musik atau ekstrakulikuler yang sesuai dengan hobinya. Kemudian, yang paling dasar dilakukan adalah kegiatan pengajaran keterampilan membuat telur asin dan berjualan di sekolah untuk menyiapkan peserta didik berkebutuhan khusus agar mampu terjun di masayarakat. Mengingat bahwa, ABK (tunagrahita ringan) perlu pembelajaran life skill atau bina diri.

Berdasarkan hasil wawancara dengan peserta didik atau ABK (tunagrahita ringan) maka, terdapat persamaan, kemiripan dan perbedaan sebagai berikut: terdapat persamaan dari ketiganya yaitu 1) Memperoleh pengetahuan, 2) Menggunakan metode permainan, ceramah dan tanyajawab 3) Media gambar mini, LCD, power point dan kisah inspiratif. Hal ini sejalan dengan teori yang dikemukakan oleh Romlah (2013: 17) bahwa "bimbingan kelompok adalah salah satu teknik bimbingan yang berusaha membantu individu agar dapat mencapai perkembangannya secara optimal sesuai dengan kemampuan, bakat, minat serta nilai-nilai yang dianutnya dan dilaksanakan dalam situasi kelompok". Berdasarkan pernyataan tersebut maka, dapat disimpulkan bahwa melalui pemberian layanan bimbingan kelompok bidang karir bagi peserta didik berkebutuhan khusus tunagrahita ringan maka, guru BK berupaya membantu peserta didik memperoleh pengetahuan dan mengembangkannya secara optimal berdasarkan bakat, minat dan kemampuan yang dimilikinya.

\section{KESIMPULAN}

Evaluasi dalam layanan bimbingan kelompok bidang karir bagi ABK (tunagrahita ringan) berupa evaluasi proses dan hasil yang dilakukan dalam pelaksanaan kegiatan layanan. Evaluasi proses dilakukan langsung oleh guru bimbingan melalui pengamatan/observasi menggunakan instrumen yang tersedia dan evaluasi hasil dilihat dari pemahaman yang diperoleh peserta didik menggunakan instrument yang tersedia, secara keseluruhan evaluasi proses dan hasil diberikan untuk melihat tingkat keberhasilan layanan yang diberikan.

Layanan bimbingan kelompok bidang karir bagi peserta didik berkebutuhan khusus di SLB Negeri Kandangan telah berjalan dengan optimal dan hasil yang diperoleh bahwa layanan yang diberikan memiliki pengaruh terhadap pengetahuan peserta didik tunagrahita ringan terhadap materi yang disampaikan (progresif).

\section{DAFTAR PUSTAKA}

Abidin, Zainal dan Alief Budiyono. 2010. Dasar-dasar Bimbingan dan Konseling. Yogyakarta: Grafindo Litera Media.

Aqip, Zainal. 2012. Ikhtisar Bimbingan \& Konseling di Sekolah. Bandung: Yrama Widya.

Daryanto, Farid. 2015. Bimbingan dan Konseling Panduan Guru BK dan Guru Umum. Malang: Gava Media.

Delphie, Bandi. 2012. Pembelajaran Anak Tunagrahita. Bandung: Refika Aditama.

Esthy, Wikasanti. 2014. Pengembangan Life Skill Untuk Anak Berkebutuhan Khusus. Jakarta: Luxima Metro Media.

Hanur, Binti Su'aidah. 2018. "Melayani dengan Hati: Menghapus Diskriminasi dan Segregesi antara Anak Reguler dengan Anak Berkebutuhan Khusus Melalui 
Sekolah Inklusif YBKP Kota Kediri”. Jurnal al - Hikmah. Vol 6 No. 2.

Hartono. 2016. Bimbingan Karier. Jakarta: Fajar Interpratama Mandiri.

Ludin, M. Abu Bakar. 2012. Dasar-Dasar Konseling. Bandung: Citapustaka Media Perintis.

Lutfi, Isni Badiah. 2017. Impelementasi Program Bimbingan dan Konseling Bagi Anak Berkebutuhan Khusus (ABK) di SMP Negeri 32 Surabaya. Jurnal Bimbingan dan Konseling FKIP UNIPA. Vol 34 No. 2.

Mashudi, Farid. 2018. Panduan Praktis Evaluasi dan Supervisi Bimbingan Konseling. Yogjakarta: Diva Press.

Nur'aeni. 2017. Buku Ajar Psikologi Pendidikan Anak Berkebutuhan Khusus. Purwokerto: UM Purwokerto Press. 